\title{
IMAGINATION AS PART OF LITERATURE STUDY PROCESS IN SECONDARY SCHOOL LEVEL
}

\begin{abstract}
In creative culture, as well as in scientific and methodological literature, the question of how the human mind works is in its renaissance. Consequently, education content and teaching methods should also be in line with modern requirements, as pupils of today tend to reject knowledge and teaching if they do not see personal significance in them. It is important to look for new learning approaches, focused on the pupil's personality. Pupils have to become much more active participants in their learning, while teachers must perfect themselves professionally to provide knowledge, develop pupil's skills and to efficiently implement interdisciplinarity in different study fields, thus fostering pupil's cognitive interest, empathy, personality; paying special attention to learning and thinking processes (how one learns and how one thinks). Therefore, the question that arises is how to associate critical thinking with creativity and how to promote creativity, developing the pupil's imagination as a personality cognition promoting factor. The aim of this article is to draw attention to the promotion of imagination in secondary school literature study process from three aspects: imagination and language; imagination and co-operation; imagination and creation. A topical problem is how to promote a versatile imagination in the pupils through various pedagogical means, and how the competence of secondary school pupils acquired during school hours is related to the importance of imagination in thinking and to the synthesis of acquired knowledge, creating new original conclusions, cultivating these pupils' self-expression and self-experience.
\end{abstract}

Keywords: cognition, co-operation, imagination, self-expression, study process.

\section{Introduction}

Research on creativity often refers to an essential component of thinking processes i.e. imagination. The phenomenon of imagination is a subject of philosophy, psychology and pedagogy. Traditionally, imagination is 
explained as a mental process, creating something new in consciousness in the form of a picture, a vision, an idea, and a figurative concept. The notion of imagination is often understood in a simplified way and as synonymous with the notion of imagining: to characterize, to show something different than it is in reality, to portray, for example, to imagine what is desired to be real. Classically, creativity and imagination are thought to be the ability to find new solutions to a particular problem (Guilford, 1967). Imagination is a natural feedback that each person is endowed with, for it creates feelings, and feelings lead to action. Imagination is like a tool for self-programming (Vidnere, 2015). Imagination and associations are the foundation of deep thinking (Smith \& Colby, 2007) and memory enhancement, therefore Buzan (2008) offers a witty game of letters and notions called "I AM", where I stands for imagination, A for associations and $\mathrm{M}$ for memory.

Understanding a literary text from the aspect of content, as well as form, has always been a challenge, as one can often observe rational associations, the inertness of imagination, the inability to get into the characters or situations. Literature teaching methodology researcher in Latvia and Doctor in Pedagogy Rudzitis (2000) points out that one of the causes of failure is the inadequacy of teaching methods to the specificities of the study of fiction as a verbal art form. This discrepancy manifests itself in the excessive application of logic to these art works, the emotional imagery impoverishment (Rudzītis, 2000).

Why is it in secondary school specifically that it is important to master literature as an art subject? Because in the secondary school level pupil's perception of the world begins to resemble that of an adult; pupils become more critical and demanding towards themselves and teachers, secondary school pupils are better able to see the interdisciplinarity of their subjects, they become aware (although occasionally they do not) of the importance of literature teaching to their future life. Instructional activity, secondary school level included, is one that promotes or impedes motivation of personal activity, extends pupil self-experience, because the competence acquired in literature lessons is related to the following manifestations of emotional intelligence: recognition and management of one's emotions, recognition of other people's emotions, empathy, ability to form diverse relationships with peers (Šteinberga, 2013). Therefore, the development of imagination in the literary learning process is manifests itself as a significant component of self-expression, self-assertion and introspection.

When looking for an answer to one of the most important questions about the conditions for thinking and knowledge, researchers in philosophy, psychology and pedagogy are confronted with the problem of imagination. Even Aristotle (2008) paid attention to the fact that thinking was impossible without images. Imagination as a challenge for thought is one 
of the research subjects of hermeneutics by Gadamer (1999) and Ricoeur (1976), emphasizing that preconditions for personal freedom and thinking are based on imagination. Creativity and imagination are an integral component of many fields of knowledge and skills, i.e. science, mathematics, business, design, and arts. A pedagogical activity that stimulates imagination develops thinking, for it integrates what has been learned in the other subjects and reveals the interconnections between different fields. Albert Einstein's conclusion - "Imagination is more important than knowledge. For knowledge is limited to all we now know and understand, while imagination embraces the entire world, and all there ever will be to know and understand" - has already become an aphorism (Fadel, Bialik, \& Trilling, 2017, p. 74).

In phenomenology, imagination is viewed not as a reproductive and also as a productive act of consciousness; imagination is not an empty play of images, it is a tool of truth and creative discernment, and thus the preconditions for human freedom based on imagination (Narkēviča, 2010). However, to be free is to create. This is why in a literature class it is essential to organise perception of the text as a creative thinking activity. The development of imagination ensures that learning activities are not only reproductive, they are also creative.

\section{Imagination and Language}

From the point of hermeneutics, human experience derives its ultimate fulfilment not from any aggregated knowledge but from openness to the experience that comes with life experience. (Ricœur \& Thompson, 2016) in his studies also goes from phenomenology of imagination to hermeneutics of imagination, viewing imagination as a language dimension, because language is the place where imagination is recorded, strengthened in longevity (Narkēviča, 2010, pp. 7-8).

Literature is an art of the word. What does it mean to master a language? Hermeneutics offers a philosophical conclusion that "we are linguistic residents" because "language does not manifest in statements, it is realized as a conversation, as a unit of meaning which is shaped by a question and an answer. Any statement is a fragment of a dialogue, a conversation, through which and in which the language lives" (Gadamer, 2002, p. 12). In the context of hermeneutics, Gadamer (2002) explains that understanding is misunderstanding at the same time. Consequently, the subject of understanding is the language itself, where understanding becomes an endless task of human life. Significant is the way to get behind the pronounced, closer to the essence of language, also to soul of what has been expressed, and then understanding the text becomes the continuation 
of the conversation started. Gadamer (2002) adds something important: the soul of hermeneutics is characterized by the ability to recognize another truth; the fundamental principle of philosophical hermeneutics is a conversation and a dialogue.

"Paul Ricoeur shows that the reader's relationship with the text is their relationship with the world that the text offers us. A read goes beyond the borders of the linguistic theory. This is an existential activity in which the reader, by following the meaning of the text, finds the reference - the world showed by the text. The culmination of a read is the acquisition of the meaning of the text, which the reader appropriates (...)" (Ābels, et al., 2015, p. 421), thus, reading is a creative activity that results in new images and imaginative models. When addressing different levels of language use, notes that besides an informative nature a language also carries a specific kind of beauty, because speech creates reality, presenting human knowledge of the world in its different aspects (Tinjakova, 2018, p. 15).

The text comprehension process makes one ask various questions. Why, when reading the same text at different stages and situations of life, the same reader notices new details that they did not notice before? Why are new reading variants continuously appearing in the text? What is it that gives the language a dimension of depth? Gadamer explains that there a meeting takes place between the reader and the worlds of the text, and he emphasizes the purpose of the interplay between imagination and understanding, as if one could somehow get behind what has been said (Gadamer, 2002, p. 67). In these interactions between understanding and imagination, when imagination is reproductive, yet also a productive act of consciousness, the pupil's self-realization takes place. The so called "full picture" continues beyond the work of art and text, it should be perceived with the "third eye" or the "sixth sense". The essence lies in the search for differences, in noticing nuances, in training the focus, in alertness.

The cognitive process activity (perception, conception, memorization, comprehension and others) is stimulated by the pupil's cognitive process activity. Depending on the purpose of the teaching, learning reflects the nature of studies; it can be reproductive, interpretative or productive (Žogla, 2001).

Pupils themselves appreciate the literature lessons. Last year's pupil of Secondary School wrote: "Literature inspires me. Every time I read something new, I understand how much I still have to discover about myself. A new book is a new chance to discover something new and unknown. Literature is a science linked to philosophy, imagination, language, understanding of life. Literature is like a synonym to the concept of thinking on the highest level. Sophisticated thinking is start for a good life. Book reading improves 
personality and inner faces of one's character, it highlights how different and unique we all are."

\section{Artistic Inquiry and Imagination as Co-operation in Literature Lessons}

Philosophical hermeneutics is opposed to an overly narrow understanding of a text, it is explained as a semiotic structure closed in itself that has no connection to reality (Ābels, et al., 2015, p. 419). A text (including those of fiction) acquires its meaning if it becomes part of a person's search for truth and part of knowing oneself, if the text is able to reach the thoughts of its reader, to change their attitude and behaviour. Often poetic texts are those that are capable of reaching those layers of human existence that are difficult to rationalize and to be expressed in a language. Owing to the means of expression of the poetic language, narration or poem is able to "collect" the messy and fragmentary human life experiences in a single, coherent whole (Ābels, et al., 2015, p. 422).

Therefore, it is important to teach literature in secondary school as an art subject. This realization has been well explained by Riga Technical University professor and Doctor in Psychology Šteinberga in an interview about School Reform in Latvia: "Once the secondary school level is reached, there is a need to learn the foundations of philosophy, to develop their own views on life, to create conscious values. There is no use to talk about values any sooner than when they are understandable and comprehensible. Each type of attitude has its sensitive developmental period. (...) We worry that the child has no motivation, although first we need to know whether what we are doing corresponds to their age and their needs" (Klanska, 2018, p. 10). Art cannot be understood at a glance. In order to understand the symbol language and the subtexts, the pupil must be mature enough, on their intuitive way to internal freedom. In the same interview professor from the University of Latvia and Doctor in Pedagogy Špona added: "Learning is self-expression. If one does not have the chance to express themselves in the class, then they do not know what to do further with themselves in order to pursue a purposeful development. Freedom is free will and self-realization" (Klanska, 2018, p. 10). A pupil's competence will only arise if they come to the conclusion by themselves. A conclusion is arrived at through reason, through teacher-pupil cooperation. Human thinking abilities mature not by themselves, they only do so in contact with the world, its objects and individuals (Piaget, 2002). Therefore, the result of literature learning is often not immediately visible and measurable, since the process of co-operation itself is more relevant than the apparent result. It is precisely the openness to new experiences, 
through interaction, that directs students towards the subjective quests for meaning.

Some researchers have noted that creativity is highly determined by motivation. The scientific creativity is highly dependent on motivation, especially intrinsic motivation. Therefore, the overall classroom environment, aimed at improving pupils' intrinsic motivation is essential (Zulkarnaen, Supardi, \& Jatmiko, 2017).

The literature learning process has the advantage of using artistic inquiry as a co-operation where there is a mutual exchange of spiritual values between pupils, an also between pupils and teachers, where differences of opinion are tolerated and even desirable as a manifestation of critical thinking; the student searches, analyses, discovers interrelations, develops the skill to evaluate, interpret, to express an opinion, to express creatively. It is important not only to coordinate literature as an art subject with the content and methodological basis of other art subjects, but also to plan it as a subject that organises the experiences of values.

Rudzitis (1994) emphasizes the value orientating aspect of fiction as an art of words and suggests that the study of literature in school should be interpreted broadly as a circulation process of culture, particularly aesthetic culture, in which a significant place is given to the revelation of life and art values. The actualization of life and art values, and the development of such skills in pupils are all methodically important for these pupils to be capable of defining and discovering values important in their own lives (Rudzitis, 1994, p. 5). Fiction art works, their ideas, images, ideals, artistic values are perceived, felt and understood as aesthetic experiences, therefore it is important to seek a balance between the intellectual and emotional components by the use of both reproductive and productive imagination and by promoting self-actualization.

\section{Imagination and Creation}

The understanding of art, including literature, is perfectible and directable. An artwork is never really fully discoverable and understandable, therefore, to a greater or lesser extent it cannot be fully finished in the imagination. Contact with an artwork is at the same time watching it, experiencing it, understanding it, transforming it creatively in the imagination, subjecting it to personal interpretation and enjoyment and satisfaction for the success of these activities.

Creativity in learning process can take many forms, although usually it is linked to artistic creativity and creation of artworks. Purēns notes that several components are important in this process: topicality, experience, emotions, opinions and heritage. For a pupil, creation of an artistic artwork 
can be a cognitive process where they can better discover regularities in art creation and cultivate self-actualization (Purēns, 2017, p. 97).

Creativity in literature lessons can be acted in different ways, both as cocreation and as creative writing, as the generation and implementation of new ideas, as well as co-operation, for example, by working in groups and by conveying their ideas to the members of the group, classmates, teacher, thereby promoting mutual understanding, exchange of opinions, mutual trust. The creative process helps self-expression, develops self-esteem. Creativity and imagination tasks in literature lessons develop skills, selfexamination, and they become more attentive towards the language, the pleasure of learning a language is growing. The Secondary School pupils themselves, in spite of their lack of education in pedagogy, intuitively value and acknowledge the importance of the literature study process and the creative imagination tasks to their personality development. This is evidenced by a reflection written by a pupil: "Literature is not just a study subject, it is a vast science in which everyone can find their place even if they do not like to read or write. Each autumn our school produces a performance of poetry, music and movement. I participated in it last year and I was surprised both by my ability to read a poem in front of a large audience and by the fact that my involvement in this event touched me quite a bit, creating a pleasant emotional uplift. This indicates that the activities related to literature can have diverse effects, and for me it is positive. It seems to me that it depends on the topic and that it is important to participate actively. Even if your contribution is small, it feels like you are part of everything. It's all based on the hidden power of literature, which makes you get to know and understand yourself, because before this performance I did not expect that these would be my memories. The tasks range from learning a poem by heart, text reading, visualization to presentation and research. I am lazy doer, but when really go into it, literature does not let me go, because literature is study of oneself. I call this process self-exploration. In my opinion, people must be encouraged to take interest in literature as it offers more opportunities and makes people freer."

The words of this pupil are conformed by research of philosophers and educators. For example, Play, Symbol, Festival - these are the objects of Gadamer's (2002) philosophical hermeneutics study where some of the qualities of the play mentioned are the following: play as a free impulse; the aimless rationality of the play; a play involves co-playing; a play as reflection; a play as a communicative action, which all together develop the "depth dimension of perception" (Fadel, Bialik, \& Trilling, 2017). This is a peculiar reinterpretation. All this is actualized in the self-expression of the pupils. Any contact with art must be developed and directed. An artwork is "discovered"; it can be more or less completed in the imagination. This 
apparent uncertainty, the acquisition of certain fast-evaluable results, problems in evaluating creative work lead to discussions about the usefulness of the literature subject (Rudzitis, 2000).

Literature education promotes aesthetic sensitivity and language development, the development of fancy and communication, empathy, identity formation, the formation of a social opinion and knowledge on reality (Skalberga, 2012). Like art, literature does not conform to normativity, it encourages critical thinking and awareness of your national identity as part of the world cultural space, it develops self-expression and self-confidence in a person, forms a student into a free, responsible, independent, creative personality.

\section{Methodology}

The work has been drafted under the cultural-historical approach and with attitude that humans are the highest value in society. Studying literature as an art subject is not possible without gaining philosophical insights on the significance of imagination its cultivation in pupils in the learning process. Therefore, the following methods are used in this study: literature analysis, revealing interconnectivity, analysis of one's own experience.

\section{Results}

During the research theoretical correlations were discovered between imagination and language, imagination and co-operation, imagination and creativity, revealing the significance of promoting imagination in the literature study process as well as in cultivating self-expression in the students (see Table 1).

\section{Discussion and Conclusions}

Literature essays, functions of literature, its teaching at school, artistic and ethical values, artistic perceptions have always been subject to acute arguments and discussions, and the literature subject should justify its meaning and significance from time to time. For example, one might defend the fictional cat from a Kārlis Skalbe's story for children "The Cat's Mill", who from an everyday point of view had an unsuccessful business project. When the cat loses it all, he doesn't lose his self-respect and continues to believe that people have good in them. This story repeatedly has raised in the Latvian cultural space, as well as in the context of education program planning discussions on fundamental values and the role of fiction in the 
Table 1. Interconnections with imagination in the literature study process

\begin{tabular}{|c|c|c|c|}
\hline $\begin{array}{l}\text { Interconnec- } \\
\text { tion }\end{array}$ & $\begin{array}{l}\text { Imagination and } \\
\text { language }\end{array}$ & $\begin{array}{l}\text { Imagination and } \\
\text { co-operation }\end{array}$ & $\begin{array}{l}\text { Imagination and } \\
\text { creativity }\end{array}$ \\
\hline Detection & $\begin{array}{l}\text { Imagination as } \\
\text { an initiator of } \\
\text { new thoughts or } \\
\text { associations } \\
\text { "Language is } \\
\text { the place where } \\
\text { imagination } \\
\text { is recorded, } \\
\text { strengthened in } \\
\text { longevity" } \\
\text { (Narkēviča, 2010, } \\
\text { p. 8). }\end{array}$ & $\begin{array}{l}\text { Imagination as } \\
\text { co-operation } \\
\text { Exchange of } \\
\text { individual ethical } \\
\text { and aesthetic } \\
\text { values, interests and } \\
\text { creation of joy and } \\
\text { empathy } \\
\text { "Human thinking } \\
\text { abilities mature not } \\
\text { by themselves but } \\
\text { in contact with the } \\
\text { world, its objects } \\
\text { and individuals" } \\
\text { (Piaget, 2002). }\end{array}$ & $\begin{array}{l}\text { Imagination as } \\
\text { co-creation and new } \\
\text { creation } \\
\text { Openness to a new } \\
\text { experience because } \\
\text { of one's own } \\
\text { experience } \\
\text { "Imagination is } \\
\text { art hidden in the } \\
\text { depths of the soul, } \\
\text { without which we } \\
\text { would have no } \\
\text { cognition at all" } \\
\text { (Kant \& Kūlis, } \\
\text { 2011). }\end{array}$ \\
\hline Understanding & $\begin{array}{l}\text { Conversation, dia- } \\
\text { logue } \\
\text { Text reading (work } \\
\text { with text) as a } \\
\text { creative activity } \\
\text { Grasp and } \\
\text { imagination - } \\
\text { self-realization } \\
\text { Imagination as a } \\
\text { reproductive and } \\
\text { productive act of } \\
\text { consciousness }\end{array}$ & $\begin{array}{l}\text { Interactive } \\
\text { co-operation: } \\
\text { pupil - pupil } \\
\text { pupil - teacher } \\
\text { teacher - teacher } \\
\text { Artistic inquiry - } \\
\text { Understanding } \\
\text { yourself and the } \\
\text { world through } \\
\text { artwork } \\
\text { Pupils come to } \\
\text { conclusions by } \\
\text { themselves - } \\
\text { Self-actualization }\end{array}$ & $\begin{array}{l}\text { Synthesis } \\
\text { Deep learning, } \\
\text { generalization } \\
\text { Extended } \\
\text { abstraction } \\
\text { Play - facilitator of } \\
\text { self-expression }\end{array}$ \\
\hline Application & $\begin{array}{l}\text { New images } \\
\text { (figurative models) } \\
\text { Introspection }\end{array}$ & $\begin{array}{l}\text { Value-orientating } \\
\text { co-operation } \\
\text { Self-guided learning }\end{array}$ & $\begin{array}{l}\text { Creative work } \\
\text { Self-expression in } \\
\text { action }\end{array}$ \\
\hline
\end{tabular}

learning process. The most important message in this story is in the subtext message of love and forgiveness, because "Why should one amplify the pain? Let us amplify the joy instead! (Skalbe, 1998)". This realization is still relevant today in the $21^{\text {st }}$ century. This problem was also discussed in a Latvian television series episode where the main question was whether Latvian literature could be dangerous to mental health (Latvijas Televizija, 2017). Literature and pedagogy science experts contradicted the view that only successful people should be portrayed in literature since art works filled 
with problem situations and issues could affect pupils' mental health. This view demonstrates that sometimes vulgarization, simplification, superficial understanding of literature as a work of art takes place, because an art work does not necessarily need to have a didactical purpose. Educational, value orientating goal emerges in the process of analysing and interpreting the artwork by contemplating, co-experiencing and co-creating it.

By analysing the literature of philosophy, psychology and pedagogy, the author broadens the understanding of the role of imagination in thinking in the process of studying literature in Secondary School and reveals correlations where imagination is a factor contributing to the personal cognitive activity. The study and analysis of the theoretical literature reveals the interrelations between imagination and language, where imagination is an initiator of new thought and association; significant interrelations between imagination and cooperation, where interactive collaboration provides for the exchange of individual ethical and aesthetic values; and the close interrelations between imagination and creation, which through cocreation and novel creation provide openness to new experiences and strengthens self-confidence. The versatile imagination of pupils can be stimulated if the teacher is aware of the importance of imagination in thinking processes and various pedagogical tools such as creative tasks, the creation of joy and empathy, value-orienting co-operation and creativity, aimed at encouraging motivation and self-expression in action, illustrated in this publication by author's self-experience and passages from pupil writings. Imagination stimulating activities develop thinking, because it integrates what has been learned in other subjects, discovering the interconnections between different fields.

Literature critic and Doctor of Philology Bībers (1986) says that fairytale heroes love paths. However, these paths are not so much paths in the world, paths leading to the transformation of the world, as they are paths leading to oneself, self-exploration and transformation of the self. These words also apply to the path of cognition and knowledge acquisition as a whole, because only through the self-exploration and self-improvement is it possible to discover, achieve and create something. When being aware of the meaning of imagination, it is possible to enrich the literature lessons as well as the emotional world and the world of values of the pupils, stimulating both emotional and logical thinking processes and discovering a creative thinking energy in oneself.

There is no unified understanding of the essence of pedagogy, educational science, pedagogical psychology, art, and culture. Also, the teaching methodology stands for not one single, universally productive teaching model, it directs teachers' thinking in a way that they can look for and find optimal options for co-operation with the pupils, in accordance 
with the professional competence of the teacher. In the literature learning, the process itself is often more important than the measurable results, creating long-term feedback and student self-realization, as one of the tasks of the literature teacher is to develop pupils' self-activity and selfexpression. "The highest human freedom is to interpret yourself into the most beautiful sound that one can make of themselves. This is the ultimate purpose" (Ziedonis, 1999). The author would very much like to believe that, in the framework of School Reform in Latvia, literature studies in secondary school level will rise to a new quality, because the literature learning process develops imagination, imaginative and analytical thinking, promotes the subtle mental force that forms a person into a personality with a critical mind and a sensitive heart into a free, responsible, independent and creative personality.

\section{References}

Aristotle (2008). Poētika (Poetics). Ģiezens, A. (Transl.). Rīga: Jāņa Rozes apgāds.

Ābels, G., Bičevskis, R., Dāboliņ̌š, A., Derflingers, B., Gedina, L., Hefe \& O., Kiope, M. (2015). Kants, Heidegers un dzives pasaule (Kant, Heidegger and the World of life). Riga: Institute of Philosophy and Sociology, University of Latvia.

Bībers, G. (1986). Drāmas teorijas jautājumi (Drama Theory Questions). Rīga: P. Stučkas Latvijas Valsts universitāte.

Buzan, T. (2008). Efektivas mācǐšanās rokasgrāmata (The Buzan Study skills handbook). Teibe, I. (Transl.). Rīga: Jāña Rozes apgāds. (Original work published 2007).

Fadel, C., Bialik, M. \& Trilling, B. (2017). Četru dimensiju izglitiba (Four-dimensional education: The Competencies learners). Lielvārde: Lielvārds. (Original work published 2015).

Gadamer, H. G. (1999). Patiesiba un metode (Truth and Method). Šuvajevs, I. (Transl.). Rìga: Jumava. (Original work published 1979).

Gadamer, H. G. (2002). Skaistā aktualitāte: Māksla kā spēle, simbols un svētki (The Relevance of the Beautiful: Art as Play, Symbol and Festival). Šuvajevs, I. (Transl.). Rìga: Zvaigzne ABC. (Original work published 1977).

Guilford, J. P. (1967). The nature of human intelligence. New York: McGraw-Hill.

Kant, I. \& Kūlis, R. (2011). Türā prāta kritika (Pure mind Criticism). Rīga: Zinātne.

Klanska, D. (2018). Iedzīvināsim pieeju mācīties darīt un jebkuru soli sāksim ar attieksmi (Let us revitalize our Approach to Learning how to be active and let us start with our Attitude). Izglitiba un kultūra, 2(534), 10-11.

Latvijas Televīzija. (2017, October $20^{\text {th }}$ ). Vai latviešu literatūra ir bīstama cilvēka psihiskajai veselïbai? (Is Latvian literature dangerous to personal mental health?) [Television series episode]. In: LTV1 Kultūršoks. Rīga: Latvijas Televīzija.

Narkēviča, Ž. (2010). Iztēle un valodas jaunrade Pola Rikēra filosofijā (Imagination and Creativity of Language in the Philosophy of Paul Ricoeur). Doctoral dissertation. Retrieved from https://dspace.lu.lv/dspace/handle/7/4548. 
Piaget, J. (2002). Bèrna intelektuālā attistiba (The Construction of Reality in the Child). Meinerte, S. (Transl.) Rīga: Pētergailis. (Original work published 1937).

Purēns, V. (2017). Kā attīstīt radošumu (How to develop creativity). In: Didaktika. Kā attistit kompetenci (Didactics. How to develop competency). Rīga: RaKa.

Ricoeur, P. (1976). Interpretation Theory: Discourse and the Surplus of Meaning. Fort Worth, TX: Texas Christian Univ. Press.

Ricœur, P., \& Thompson, J. B. (2016). Metaphor and the Main Problem of Hermeneutics. In: Hermeneutics and the human sciences. Cambridge, United Kingdom: Cambridge University Press.

Rudzītis, J. (1994). Metodiski materiāli latviešu literatūras skolotājam (Methodical materials for Latvian literature teachers), Vol. 1. Rìga: Izglìtība.

Rudzītis, J. (2000). Literatūras mācỉbas skolā (Literature studies at School). Rīga: RaKa.

Skalbe, K. (1998). Kaķī̌sa dzirnavas (Cat's Mill). In: Duka, V. (Ed.), Pasakas (Children's stories) (pp. 111-124). Rīga: Atēna. (Original work published 1913).

Skalberga, A. (2012). Vidusskolēna literārās kompetences veidošanās (Formation of HighSchool Student's Literary Competence). Doctoral dissertation. Retrieved from https:// dspace.lu.lv/dspace/handle/7/4834.

Smith, T. W. \& Colby, S. A. (2007). Teaching for deep learning. The Clearing House. A Journal of Educational Strategies, Issues and Ideas, 80(5), 205-210. DOI: 10.3200/ TCHS.80.5.205-210.

Šteinberga, A. (2013). Pedagoğiskā psiholog̣ija (Pedagogical psychology). Rīga: RaKa.

Tinjakova, E. A. (2018). Filozofija daet kljuch $k$ mezhdiciniplinarnomu padhodu v izucheniji jazika (Philosophy provides the key to an interdisciplinary approach to language learning). Moskva, Russia: Direkt-Media.

Vidnere, M. (2015). Iztēle: psihologíija un terapija (Imagination: psychology and therapy). Rìga: RaKa.

Ziedonis, I. (1999). Par iedvesmu (On Inspiration). In: Konste, A. (Ed.), Raksti 12 sējumos (pp. 31-36). Rīga: Nordik.

Zulkarnaen, Supardi, Z. A. I., \& Jatmiko, B. (2017). Feasibility of creative exploration, creative elaboration, creative modeling, practice scientific creativity, discussion, reflection (c3pdr) teaching model to improve students' scientific creativity of junior high school. Journal of Baltic Science Education, November 1, 2017, 1020-1034.

Žogla, I. (2001). Didaktikas teorētiskie pamati (Theoretical Basics of Didactics). Rīga: RaKa. 